\title{
Between Two Fires: Mayangna Indians in Post-Revolutionary
}

\section{Nicaragua, 1979-1990*}

Nathaniel Morris, New College, University of Oxford

The predominant Mayangna narrative of the Nicaraguan Civil War holds that the Miskitu 'tricked' them into joining the conflict. However, I argue here that the Mayangna leadership and the Sandinista government were also responsible, as Sandinista denial of the importance of ethnic difference in Nicaragua allowed Miskitu nationalists, using the language of the religion, to co-opt Mayangna leaders, while subsequent Sandinista violence turned Mayangna civilians against the Revolution. Accusations of 'trickery' stem from later Mayangna disillusion with the war and from problems with the autonomous political system set up in its wake, which encourages the Mayangna to underplay the role of their own leaders and the Sandinista government in embroiling them in the conflict. This one-sided narrative, however, increasingly defines Mayangna interpretations of their very identity as a people.

\section{Keywords: Nicaragua, Revolution, Mayangna, Miskitu, Sandinistas, Contras}

In 1985, in a speech in Bitburg, West Germany, Ronald Reagan announced: 'I am a Laotian, a Cambodian, a Cuban, and a Miskito Indian in Nicaragua. I, too, am a potential victim of totalitarianism'. By then the Miskitu, Nicaragua's largest

\footnotetext{
* The final, definitive version of this article was published in 'Bulletin of Latin American Research,' Vol. 33, Issue 2, April 2014, pp.203-218. It is available online at http://onlinelibrary.wiley.com/doi/10.1111/blar.12119/full
} 
indigenous group, were four years into a bitter, US-sponsored conflict with Nicaragua's Sandinista government, which polarised public opinion across the world. But amid the 'solidarity campaigns' on both sides and a number of fierce academic disputes (compare, for example, Dunbar Ortiz, 1986, and Nietschmann, 1989), very few were aware that the Mayangna, Nicaragua's second largest Indian group, were also caught up in the fighting.

By the end of 1982, more than three hundred Mayangna - or 'Sumu' as they were known before 1998 - had joined their Miskitu neighbours in the two main regional contra forces, the FDN ('Nicaraguan Democratic Force') and MISURA ('Miskitu, Sumu and Rama United'), while many others had been drafted into the EPS ('Popular Sandinista Army'), and well over three thousand Mayangna civilians around half the total Mayangna population - had fled their homes for refugee camps across the border with Honduras (Americas Watch, 1987).

The polemic that continues to surround the issue of Miskitu participation in the Nicaraguan Civil War (see Dennis, 1993, for an overview of the literature) has stymied discussion of the role of the Mayangna in the conflict. But this episode provides an intriguing opportunity to explore the dynamics of ethnic politics in Nicaragua, while further offering insights into the nature of Latin American ethnic mobilisations, inter-Indian relations, and the failures of leftist revolutionary movements to engage with indigenous bases of support.

There is a lack of published secondary materials on the Mayangna (Göetz von Houwald's resolutely anti-Sandinista study, 'Mayangna' (2006), being the notable exception). This article is therefore based primarily on fieldwork conducted in Nicaragua. I spent five weeks in both central and regional archives, searching for documents relating to the political, social and military situation in the northeast of the 
country between 1979 and 1990. I spent another five weeks interviewing Mayangna individuals who had taken part in the events of the period, to fill gaps in the documentation, access the collective memories of the indigenous communities at the centre of my research, and uncover historical discourses preserved only in oral traditions. In the interests of transparency - and to give credit where it's due - I have cited the real name of each interviewee, except when asked not to.

It quickly became apparent that the idea that the Miskitu somehow 'tricked' the Mayangna into mobilising against the Sandinistas has passed into the collective consciousness of the Mayangna as a people, and was cited by every interviewee regardless of their background. With most Mayangna leaders now allied with the Sandinista-run central government against the Miskitu-dominated regional government of the RAAN (Northern Atlantic Autonomous Region), this view fits nicely with contemporary Mayangna political needs. However, while coercion and deception were certainly used by Miskitu commanders to recruit Mayangna individuals, this interpretation underplays the role of the Mayangna leadership and the Sandinistas in formenting conflict on the coast.

Based on my research, I argue instead that structural conditions allowed the ethno-political radicalism of Miskitu leaders to influence the Mayangna. After outlining the historical relationship between the two groups, I will show how a lack of political sophistication on the part of the Mayangna leadership, together with Sandinista ignorance, dogmatism and a tendency to violence, eventually resulted in the mobilisation of around half the Mayangna population against the Revolution. I further argue that Sandinista compromise was important in subsequently persuading the Mayangna to demobilise, which attests to the key role the Sandinistas played in provoking the conflict in the first place. This Sandinista compromise, paired with 
Miskitu abuses during the war, led to a shift in Mayangna allegiance from the rebels to the government. This, I argue, has influenced the Mayangna interpretation of their entire history as a people, as they increasingly define themselves in opposition to the Miskitu - reinforcing the Mayangna narrative of Miskitu 'deception' as the key factor in their mobilisation against the Sandinistas.

\section{Regional History}

The Atlantic Coast had alternately been a British protectorate and an independent 'Miskitu Kingdom' from the early seventeenth century until its official incorporation into Nicaragua in 1860. The Miskitu emerged as an ethnic group distinct from neighbouring Indian tribes during the colonial era. While the peoples of the region had long raided as well as traded with one another (Carey, 2002), in the early seventeenth century the coast-dwelling ancestors of the Miskitu acquired firearms from European buccaneers, tipping the local balance of power firmly in their direction. These proto-Miskitu, as intermediaries in the relations between Europeans and the other Indians living in the region, soon began to view themselves in opposition to their inland neighbours - the ancestors of the Mayangna (Helms, 1969).

The Mayangna today live mainly in the isolated, mountainous country around the north-western mining centres of Bonanza, Rosita and Siuna, but Mayangna tribes had historically dominated central and eastern Nicaragua, as attested to by the multitude of Mayangna place names that survive across these areas (Dolores Green, n.d.: 16-17). But while they were largely able to resist Spanish attempts to invade their territory from bases on the Pacific (Gould, 1998: 76), the Mayangna increasingly succumbed to Miskitu raiders from the Atlantic and began a steady retreat into the more remote fastnesses of the interior that continued even after the British gave up the 
Atlantic Coast in 1860. By then the Mayangna population had declined from a possible pre-contact total of over 30,000 (Newson, quoted in Green, 1989: 13) to around 5-6000 (Conzemius, 1929: 14), as wars with the Spanish and Miskitu slaving expeditions gave way to increasing assimilationist pressures from both mestizo Nicaraguans and the Miskitu. This decline was exacerbated by conflicts between the different Mayangna tribes and a series of disastrous epidemics (Conzemius, 1932).

American mining and logging operations, and growing mestizo immigration from the Pacific, increased the pressure on the remaining Mayangna landholdings in north-central Nicaragua in the first half of the twentieth century. At the same time, Moravian Protestant missionary efforts in the Mayangna communities facilitated the spread of Miskitu cultural influence among the Mayangna. The Moravian Church arrived in the region from Germany in 1847 (Houwald, 2006: 517), and after the departure of the British, Moravian missionaries managed to convert a large portion of the Miskitu population to the new faith in the 1880s (Hale, 1994: 40-41; Hawley, 1997: 114).

Turning their attention to the Mayangna, the missionaries encouraged Mayangna resettlement in new, permanent villages built around churches, and often close to existing Miskitu communities, in place of their dispersed, seasonal settlements (Houwald, 2006: 523). This, together with the Moravian policy of preaching of the Gospel and teaching literacy only in the Miskitu language, brought the Mayangna into greater contact with both Miskitu individuals and Miskitu culture in general. This increased the tendency of Mayangna individuals to try to shed their original identity either by marrying out of the group or by abandoning their original language in order to move up the Coastal ethnic hierarchy, in which the Miskitu had a higher position. By the mid-twentieth century many of the new communities founded 
by Mayangna converts had become wholly 'Miskitu' (Houwald and Jenkins Molieri, 1975), while in several southern, 'Twahka' Mayangna communities, like Wasakín, the two groups now lived together side by side.

The complexity of this situation is belied by von Houwald, who portrays both the Miskitu and the Mayangna as coherent and historically opposed 'proto-nations'. Many Mayangna adopt a similar view of their history as a people, in part to challenge the current power of the Miskitu within the Atlantic Coast's autonomous political system. However, Mayangna antipathy to the Miskitu is also connected to a colonialera rivalry which continued into the twentieth century, when the Mayangna felt unable to use their language in public in mining towns like Bonanza and Rosita, fearful of mockery by the local Miskitu inhabitants (interview with Juan McKenzie, 2011). A report from an American Marine commander, leading a local campaign against Sandino's rebel guerrillas in the 1930s, notes that the local Mayangna '...remained hidden until our Miskito boatmen left us. It appeared that their fear and hatred of these few Miskitos had kept them away fully as much as their distrust of us' (Edson, quoted in Brooks, 1989: 324).

\section{Explaining Mayangna Mobilisation}

Somoza's regime had treated the Atlantic Coast as an internal colony, exploiting the region's resources but otherwise neglecting it (see Hale, 1994; Vilas, 1989). However, the Sandinista Revolution heralded sudden and dramatic change in the region. Proclaiming as one of their primary targets the 'integration' of the region and its peoples (FSLN, 1981, in Ohland and Schneider, 1983), the Sandinistas dramatically increased the presence of the State in the region, despatching teachers, doctors, soldiers and new revolutionary officials who sought, after centuries of 
neglect, to 'develop' the Coast in the image of the Nicaragua they wanted to build, based on the Nicaragua they already knew.

According to the testimonies of individuals from a wide range of different Mayangna communities, early Mayangna experiences of the Revolution were largely positive. The Revolution built new roads and clinics in the region (INNICA, 1981: 3), and the Sandinista-led 'Literacy Crusade' benefitted the Mayangna population, which by this time ranged from perhaps six to eight thousand (Houwald, 2006). Initially the Sandinista administrators envisioned a single, nation-wide literacy campaign in Spanish, while Miskitu leaders demanded that literacy in the region should be taught only in Miskitu (Jenkins Molieri, 1986: 254). Eventually, however, SUKAWALA (Sumu Kalpapakna Wahaini Lani, or 'Fraternal Union of Sumu Communities'), the Mayangna ethnic organisation, was permitted to take charge of a literacy campaign in the Mayangna language, and enthusiastic young activists were despatched across the region in what was, many former participants recall with pride, not only the first time that many Mayangna learned to read and write $-1,449$ according to a government report (INNICA, 1981: 3) - but also the birth of Mayangna itself as a written language (Norwood, 1987).

The opening up of the Nicaraguan education system in general is another achievement of the Revolution that has a prominent place in Mayangna collective memory. Up until 1979 only two Mayangna individuals had ever finished secondary education. But with the Revolution, new schools were constructed in the key Mayangna communities of Musawás, Wasakín and Españolina, and for the first time scholarships were made widely available for Mayangna students (interview with Econayo Taylor, 2011). As Dionisio Erants, who would fight both for and against the Revolution and is now himself a teacher, recalls: 'the [Mayangna] youth were always 
in favour of the Revolution, because in that time, in 1979, we were given the opportunity to educate ourselves in our own language' (interview with Dionisio Erants, 2011).

Unlike the Miskitu, the Mayangna had no political connections with the Somoza regime or cultural bonds with its American backers that can help to explain their mobilisation against the Sandinistas (Dennis, 1981; Hale, 1994). Why then, given the troubled history of their relations with the Miskitu and positive initial experiences of the Revolution, did so many Mayangna communities ally with the former against the latter? Enrique López, a Mayangna leader closely associated with the MISURA guerrillas during the 1980s, states that: 'We knew that we had a way out through education, but we also had directions from the Miskitu leadership... they told us that we had to divide Nicaragua, that the Coast needed real independence. We were not sure about what that meant... they deceived us' (interview with Enrique López, 2011).

While this explanation conveniently excuses Mayangna leaders - like López himself - from any blame for the hardships the Mayangna subsequently faced in the Civil War, it also makes explicit the idea that radical Miskitu nationalists did exercise a powerful influence over many Mayangna. In the following section, I will show how Miskitu dominance of the Moravian Church - to which almost the entire Mayangna population adhered by 1979 - was key to the spread of this influence. This was exacerbated by the political naivety and greed of some Mayangna leaders, and by the Sandinistas, who failed to understand the nature of this ethnically defined domination (McSweeney, 2004; Hale, 1994: 192), and thus reacted violently to what they saw as Mayangna 'treason', ultimately leading many Mayangna to mobilise against them. 


\section{The Moravian Church and Miskitu Leadership}

As the Moravian Church replaced the old power of the chieftains and sukias (traditional healers) in the remaining Mayangna communities, it quickly became a central part of Mayangna ethnic identity. As the Miskitu grew to dominate the lower levels of the Moravian Church hierarchy, especially after its 'nationalisation' in 1974 (Hawley, 1997), the practical relationship between the Mayangna and Miskitu began to change radically. Miskitu individuals, in their roles as Moravian pastors, became politically and culturally influential within many Mayangna communities. As the radical ethno-nationalist ideology of MISURASATA ('Miskitu, Sumu, Rama and Sandinistas Working Together') became locally influential in the immediate postRevolutionary period, these pastors played a key role in facilitating its spread in many Mayangna communities.

MISURASATA had its roots in ACARIC (Association of Farm Clubs on the Coco River), an organisation of Miskitu agricultural cooperatives formed in 1969. ACARIC fell apart after financial problems and Somoza's co-option of its leaders, but was born again in 1974 as ALPROMISU (Alliance for the Progress of the Miskitu and Sumu). Although ALPROMISU represented the Mayangna in name, it remained dominated by the Miskitu (Molieri, 1986: 257). Later that year, in a meeting of 44 Mayangna community representatives, SUKAWALA was formed as an alternative (Houwald, 2006: 539). In April 1979 - just two months before the triumph of the Sandinista Revolution - the second General Assembly of SUKAWALA was held in Musawás to discuss past successes and to form a strategy for dealing with the 'serious situation in the [Mayangna] communities, caused by a lack of education and health services, as well as the theft of lands' (La Prensa, 07/05/1979). 
However, the Sandinistas betrayed their ignorance of the cultural complexities of the Coast by ignoring SUKAWALA and simply changing the name of ALPROMISU to 'MISURASATA', and declared that the exclusively Miskitu leadership of this organisation would now be charged with representing all of the Indian groups on the Coast (Hale, 1994: 133). This decision illustrates the Sandinistas' economistic tendency to view 'class' as more important than 'ethnicity' (Wheelock, 1980), and the fact that, as mestizos drawn almost exclusively from the Pacific and Central regions of Nicaragua, their nationalist ideology was fundamentally 'mestizo' in its conception (Hooker, 2005). 'Indian' identity in Nicaragua had long been defined in opposition to their own, 'mestizo' identity, as part of a discourse, propagated at a national level from the time of independence onwards, that aimed to justify the construction of a 'Nicaraguan' nation-state by creating a united 'Nicaraguan' - and thus mestizo - population (Gould, 1988). 'Indigeneity' was therefore defined negatively as a monolithic 'other-ness,' which obscured mestizo recognition of the complexity inherent to indigenous identity, of the troubled relationships between the different Indian groups on the Coast, and of the distinct problems and needs of each. MISURASATA leaders meanwhile avoided challenging these assumptions of Indian homogeneity, presenting themselves publicly as 'Indians' rather than 'Miskitu'. By claiming to represent all of the Indian peoples of the Coast, Miskitu leaders added additional legitimacy to their demands, which nevertheless overwhelmingly reflected the history, culture and aspirations of their people alone.

Although MISURASATA did not begin to openly confront the Sandinistas until early 1981, the message its activists and leaders had always expounded in their speeches in the indigenous communities of the region (eg. Rivera, 1980, in Ohland and Schneider, 1983), was far more radical than that expressed in its written 
statements, published in Spanish for Sandinista consumption (eg. MISURASATA, 1979; Nuevo Diario, 15/10/1980, in Ohland and Schneider, 1983). The organisation made much political capital out of the reluctance of the Sandinistas - who wanted to organise the Indians into state-owned cooperatives - to grant collective land rights to Indian communities, for whom titles to ancestral territory were a cultural necessity, rather than a simple matter of economics (eg. MISURASATA, 1980; Rivera, 1980, in Ohland and Schneider, 1983). In the absence of any meaningful political role for SUKAWALA in the new, post-Revolutionary order, many Mayangna leaders felt compelled to support the 'universal' declarations of MISURASATA, which, while failing to address any specifically Mayangna demands, nevertheless contained no anti-Mayangna content and broadly appealed to a shared Costeño identity through its demands for land titles and its attacks on mestizo 'Spaniards' (Rivera, 1980, in Ohland and Schneider, 1983).

The main body of MISURASATA's activists were Moravian pastors who had joined the organisation when it was still ALPOMISU and 'upon whom the... leadership were dependent for the activism needed to sustain the movement, and for the communication of their objectives' (Hawley, 1997: 14). Many of these pastors also worked in, or supervised, Mayangna communities, where they became spokespersons for MISURASATA. As one interviewee explains: 'The clergy always spoke against the Revolution, said that it was 'Communism', and that it would make life very different... and worse' (interview with Dionisio Erants, 2011). Miskitu pastors warned that the 'communists' were planning take Mayangna land (interview with Carlos Sander, 2011; Americas Watch, 1987; Houwald, 2006; Dennis, 1981: 282); that Mayangna 'conscripts' were really being taken off and murdered (interview with Rolando Davis, 2011); that the Sandinistas wanted to burn their churches and kill 
all the Indians (interview with Juan Frank, 2011); or even that any Indian who stayed in Nicaragua would be made into soap (interview with Hazel Lau, 2011). As one former Mayangna contra observes: 'We, the Mayangna, are dependent on the Miskitu in religious matters. Whatever they said, it was as if it was written in the Bible' (interview with Serapio Palacios, 2011).

\section{The Mayangna Leadership}

An independent and political SUKAWALA could have countered this growing militant Miskitu influence within the Mayangna communities. However, grouped politically with the Miskitu in MISURASATA, the voice of the Mayangna as a distinct minority was drowned out, and Mayangna leaders faced intense pressure to support that organisation's Miskitu leadership, which was increasingly aligning itself against the Sandinistas. Although many Mayangna leaders did not actively denounce the Revolution themselves, a few of the most important elders, like Enrique López and Meregildo Ramón of Musawás (the Mayangna 'capital') gave their full support first to MISURASATA and subsequently to MISURA, an armed offshoot of MISURASATA led by Steadman Fagoth, who declared war against the Sandinistas in February 1981. Many Mayangna now insist that these leaders were as engañado by the Miskitu as the rest of the population. The fact that they often spoke little or no Spanish, but were fluent in Miskitu, and were subject to both the anti-Sandinista influence of the Miskitu-dominated 'Indian' organisation that they had been pressured by the Sandinistas into joining, and to that of the Miskitu-dominated 'Mayangna' church, gives some weight to the idea that they were 'deceived' into turning against the government. 
However, it is important to note that when the conflict between Sandinistas and Miskitu rebels reached its initial peak in 1982, some Mayangna communities on the Río Bocay and the Río Coco - in the same war-ravaged region as Musawás evacuated south with the Sandinistas, rather than north to Honduras with MISURA. The leaders of these small communities, such as Juan Frank of Umbra, had been involved with MISURASATA and the Moravian Church but were not co-opted by the Miskitu leadership to the same extent as many others. This may in part be explained by the fact that they were regarded as less important, and therefore not offered much reward by the Miskitu for their cooperation (Juan Frank, 2011). Enrique López and Meregildo Ramón on the other hand, as the chief secular authorities of the largest Mayangna community, were promised money and rank in exchange for their support: "When the war started, they told us that "we have started the war, and the survivors will be given important positions, historic roles" (interview with Enrique López, 2011)

While these sentiments heighten Mayangna feelings that they were 'tricked' by the Miskitu into fighting a war in which they had no place, they also suggest that those leaders who made the 'trick' possible were not simply deceived themselves, but also bought out - and that some of their bitterness stems from not yet having been paid. 'They didn't keep their promise. [The Miskitu leaders] gained power, but... as a Mayangna warrior, now there is nothing for me', López, now old and ill, explained (Enrique López, 2011).

\section{Sandinista Excesses}

Ultimately, however, it was the Sandinista reaction to the growing pull of MISURASATA's 'Indianist' nationalism on the Mayangna that played the single 
most important role in provoking violent Mayangna opposition to the Revolution, as Sandinista violence against those suspected of 'disloyalty' led whole communities to flee to refugee camps in southern Honduras. These camps were run by the UN High Commission for Refugees but dominated by Fagoth's MISURA guerrillas, who were backed financially and logistically by the CIA and the Honduran Army (Hale, 1994: 265). Fleeing to these camps for 'protection' thus left Mayangna refugees vulnerable to forced recruitment into MISURA (Americas Watch, 1987).

After the first outbreak of Sandinista-Miskitu violence at Prinzapolka, in February 1981, prominent Mayangna leaders who had been involved with SUKAWALA - including Ronas Dolores Green, Livingston Frank, Eugenio Frank and Murphy Almendárez - were jailed (interview with Murphy Almendárez, 2011), and many of the Mayangna literacy campaign workers - including Rolando 'Chaolín' Davis and Juan Frank López, both of whom would work closely with the Sandinistas in the future - were arrested and interrogated (interview with Rolando Davis, 2011; see also Americas Watch, 1987: 21). After MISURA raids into Nicaragua began later that month, Mayangna communities were occupied by suspicious Sandinista troops. At the same time, however, as 'Nicaraguan citizens just like any other,' Mayangna youths faced compulsory military training and often forced recruitment into the EPS. This led to Mayangna resentment of the government, exacerbating the confrontational atmosphere in many Mayangna communities. This provoked Sandinista abuses and further Mayangna radicalisation.

It is significant that, apart from the aforementioned communities that evacuated south with the Sandinistas in 1982, the other Mayangna communities that failed to mobilise en masse against the government, such as Wasakín, Fruta de Pan, Españolina, Santa María and Mukuswas, were those furthest from the border with 
Honduras, where at the start of the war the heaviest fighting took place. Even so, the inhabitants of these communities were not forced by the initial fighting to leave their homes, and while subject to a Sandinista military presence, they had little contact with the MISURA guerrillas based many miles to the north. This eased Sandinista suspicions that the Mayangna civilians were conspiring against them with the Miskitu, lessening tensions. Although some of the youth were threatened with conscription, fleeing to Honduras was impossible, and while some managed to quietly avoid military service, others eventually joined the EPS voluntarily (interviews with Cornelio Fenley, 2011; Carlos Sander, 2011; Juan McKenzie, 2011; Juan Frank, 2011). Very few members of these communities ended up fighting for the contras.

However, the case of Musawás is a good example of how counterproductive Sandinista actions were in other Mayangna communities located nearer the frontier with Honduras. With a population of around 1500 (Houwald and Jenkins Molieri, 1975), Musawás was the largest Mayangna community, strategically situated on the Río Waspuk - one of the main routes into Nicaragua for the Honduras-based MISURA fighters. It suffered the presence of both the EPS and the Miskitu guerrillas, the latter invited into the community by Enrique López, Meregildo Ramón, and by one of the few Mayangna Moravian Pastors, Sandalio Patrón.

On 20 March 1982, Sandinista troops arrived to recruit young men for compulsory military service. They machine-gunned coconuts from the trees near the church (interview with Serapio Palacios, 2011), panicking the inhabitants, and then tried to force the reluctant draftees to leave the community. The majority of the inhabitants fled and in the confusion at least one Mayangna was killed (Houwald, 2006: 595). A few days later, a MISURA force arrived in the area, offered to 'rescue' the frightened Mayangna (interview with Dionisio Erants, 2011), marched some of 
them to Honduras (CIDCA, 1984), and took on Ampinio Palacios, Econayo Taylor and Dionisio Erants - who had all been trained militarily by the Sandinistas as EPS reservists a year before - as fighters.

A MISURA ambush at Salto Grande on 19 June, in which two MINT (Interior Ministry) officers were killed by the Mayangna recruits, led to a Sandinista 'invasion' of nearby Musawás a week later. Von Houwald calls it a 'massacre,' and claims that several young girls were raped by the troops (Houwald, 2006: 594-596), but one of his key sources for this incident, Enrique López, along with two other Mayangna who were there at the time, now explicitly deny that these took place (interviews with Enrique López, 2011; Serapio Palacios, 2011; Erancio Zeledón, 2011). What is clear, however, is that at least two Mayangna were killed, and thirty-two Mayangna were taken away by helicopter - some of whom were later tortured, or died in prison (interview with Anonymous, 2011; Americas Watch, 1987: 17-20). The rest of the population was trapped indoors during the two weeks of the Sandinista occupation, unable to gather food in the montaña (interview with Seperaida Simeón, 2011). As soon as the Sandinistas left, there was a mass exodus of the population and by late 1982 the majority had settled across the border in Honduras. They were soon joined by other Mayangna who had heard about the violence in Musawás, totalling more than 3000 people, or around half the Mayangna population (CIDCA, 1985).

\section{War, Autonomy and Mayangna Identity}

MISURA was eager to exploit the reservoirs of man-power available in the refugee camps of Mocorón, where the bulk of the Nicaraguan refugees, Miskitu and Mayangna, first settled. While some of those fleeing Musawás in 1982 were taken straight to MISURA training camps, most of the early recruitment of the Mayangna 
within the Honduran camps was accomplished through a mixture of psychological pressure, threats of violence towards potential recruits and their families (interview with Econayo Taylor, 2011), and Miskitu promises that 50,000 US marines would soon invade the country (interview with Rolando Davis, 2011), that the war would be over any day, and that victory was guaranteed (interview with Erancio Zeledón, 2011). Even officers were recruited in this way, and while they were selected for leadership positions on the basis of past military experience or educational level, they received no subsequent political or ideological training (interviews with Econayo Taylor, 2011; Dionisio Erants, 2011; Eranicio Zeledón, 2011). It's thus unsurprising that serious problems of morale and discipline soon became apparent within the Mayangna units, and that disillusion with unfulfilled Miskitu promises have reinforced the myth of the Miskitu engaño.

Many Mayangna ex-guerrillas bitterly recall their time with MISURA. The Miskitu leaders 'didn't conduct themselves well, and for that many soldiers died, both Mayangna and Miskitu, for lack of medical attention, for lack of rations, as soon as they were in the montaña, out of sight of the American journalists covering the conflict' (interview with Eranicio Zeledon). Many of the guerrillas wore second-hand uniforms, carried sub-standard weapons and equipment and lacked ammunition. 'They even charged us for aspirin,' a former officer recalls with disgust (interview with Serapio Palacios, 2011). However, the Mayangna also felt their Miskitu comrades treated them as expendable: 'We were on a mission, ten Sumus and ten Miskitos. The Miskitos stayed behind, while the Sumus had to walk first. If we encountered the enemy, the Sumus fell first, it was not just' (unnamed Mayangna commander, quoted in Americas Watch 1987: 11). The harsh living conditions exacerbated these tensions, and as one former combatant recalls: 'There were 
problems with food, but also problems of racism and contempt, all of these we saw during the war' (interview with Seperaida Simeón, 2011).

Miskitu abuses against Mayangna civilians and supposed 'informers' also angered the fighters. Miskitu guerrillas entered Musawás soon after the Sandinista occupation in June 1982, and tortured and killed a young Mayangna, Rodolfo Jacobo, accused of being a Sandinista spy (Americas Watch, 1987). Although disputed by Ampinio Palacios, it seems clear from other interviews that one of the Miskitu guerrillas involved was killed soon after in revenge, shot in the back by a Mayangna member of his own squad during a skirmish with Sandinista troops (Anonymous interviewees, 2011).

Those Mayangna refugees who had avoided incorporation into MISURA also quickly became disillusioned with life in Honduras. Some claim that many Mayangna died in the jungle before reaching Honduras (interviews with Pichardo Fernandez, 2011; Econayo Taylor, 2011), while in the camps, discriminatory Miskitu distribution policies favoured Miskitu families over the Mayangna. Although there is disagreement as to whether the food they did receive was 'rotten' (Seperaida Simeón and Pichardo Fernandez, 2011), or simply unfamiliar (Salvador Huete, 2011), it caused serious illness in children and older people. But as a minority population they could not make their complaints heard, especially at higher levels (Americas Watch, 1987: 11; Houwald, 2006: 599).

In the face of these problems, the most important Mayangna guerrilla commander, Ampinio Palacios, decided to leave MISURA with his men and go over to the FDN, the main mestizo contra group, in late 1983. Steadman Fagoth reacted violently to the news and Ampinio was arrested with his brother Serapio, but both managed to escape (interviews with Ampinio Palacios, 2011; Serapio Palacios, 2011). 
Together with around two hundred other Mayangna troops and their families, they fled Honduras and set up a rebel base inside Nicaraguan territory (Americas Watch, 1987: 23). The hundred or so Mayangna fighters who had not joined Ampinio Palacios in defecting to the FDN had nonetheless left MISURA by April 1984 (Americas Watch, 1987: 11), leaving only Enrique López, Meregildo Ramón and a handful of other leaders with the Miskitu (Frank and Erants, 2000: 62).

\section{Sandinista Compromise}

Even after the majority of Mayangna fighters deserted the Miskitu cause, the Mayangna in the camps felt it impossible to return to Nicaragua unarmed until the Sandinistas re-evaluated their nationalist revolutionary ideology (Dennis, 1993; Hale, 1994). As early as August 1981, William Ramirez, the most senior Sandinista official on the Coast, acknowledged that: 'Our main error was to treat the indigenous groups as if they were equal groups. Experience has made us see that from the ethnic point of view the interests of the Miskito, of the Sumu and of the Rama are different. They are even antagonistic, given that historically the Sumu and Miskito have been enemies' (Ramirez, 1981). But it was not until December 1984, when President Daniel Ortega announced that the Sandinistas would recognise the Atlantic Coast's right to autonomy, that the government fully demonstrated that it understood its previous, unilateral approach to the region and its peoples had been counter-productive.

Sandinista relations with the Mayangna began to improve from early 1985 onwards, as negotiations between Sandinista and Mayangna community leaders on the actual meaning of 'autonomy' began. Perhaps the clearest sign of this gradual reconciliation was the rehabilitation of SUKAWALA, which had been 'paralysed' by the arrest and interrogation of many of its leaders and activists in 1981 (interview 
with Juan McKenzie, 2011), and had ceased to function entirely by 1983 . On 10 February 1985, eighty-three Mayangna delegates came together to re-launch their old organisation under the leadership of Ronas Dolores Green, who in 1974 had been one of its original founders (Barricada, 16/02/1985).

From being no more than a footnote in Sandinista discussions of the 'Miskitu problem,' the Mayangna, represented by SUKAWALA, became partners on an equal footing with the Sandinistas and the other Coastal peoples in the Coastal autonomy negotiations. Through direct negotiations with Tomás Borge, the head of the Northern Zelaya Autonomy Comission (interview with Aurelia Patterson, 2011), SUKAWALA won the exemption of the Mayangna from Sandinista conscription. Soon after, in April 1985, the recently elected Asemblea Nacional passed a Decreto de Amnestía, proposed by Ronas Dolores Green amongst others, which specifically covered those 'Miskitu, Sumus, Ramas and Creoles detained for crimes against public order and security' and was translated into each of the languages of the coast and read out in the communities (Barricada, 30/04/1985). This helped to restore Mayangna trust in the Sandinistas, and for the refugees and ex-combatants in Honduras, harassed there as they were by MISURA, made returning to Nicaragua seem a real possibility (interviews with Dionisio Erants, 2011; Econayo Taylor, 2011).

The autonomy process and the amnesty also divided the Miskitu leadership of MISURA, which caused the organisation to splinter into pro- and anti-peace factions. The declaration of a cease-fire by the former group undermined the authority in the camps of hardliners like Fagoth, and thus as conditions continued to deteriorate for the refugees, and word spread that the Sandinistas had 'changed' (interviews with Seperaida Simeón and Salvador Huete, 2011), many Mayangna civilians and former MISURA combatants saw their chance to return to Nicaragua. 
Just how much relations between the Mayangna, the Miskitu and the Sandinistas had changed is clear from the fact that the first group of fifty Mayangna FDN fighters to return under amnesty, in November 1985, decided to directly join the EPS, which was still engaged in heavy fighting with both the remaining pro-war Miskitu and their former comrades in the FDN (interviews with Rolando Davis, 2011; Dionisio Erants, 2011). By 1986, a significant number of Mayangna were fighting for the Sandinistas, either in community self-defence militias or in the ranks of the MINT and EPS.

The rest of those Mayangna still under arms - around one hundred men (interview with Serapio Palacios, 2011) - were contras officially aligned with and supplied by the FDN, but under the command of Ampinio Palacios, who frequently carried out operations on his own initiative. His group racked up much negative press for 'abducting civilians' (eg. Los Angeles Times, 09/06/1987; Associated Press, 02/02/1988) and was by now the most serious threat to the repatriated Mayangna. At least 117 of these returnees were abducted between 1985 and 1987, in addition to others snatched from the Honduran camps, where many Mayangna remained until 1990 (Americas Watch, 1987: 24-32). In addition to his armed force, Palacios' base housed around 500 other Mayangna, including the families of his fighters, a number of refugees (interviews with Ampinio Palacios, 2011; Rolando Davis, 2011), and various prisoners (Americas Watch, 1987: 19).

Palacios's supplies began to dry up as the FDN were put under increasing strain by Sandinista advances, which culminated in 'Operation Danto' in March 1988, in which some 160 Mayangna took part on the Sandinista side (interview with Joaquín Blandón, 2011). Soon after, Palacios was persuaded to enter into a dialogue with the Sandinistas, facilitated by a Mayangna MINT officer related to one of his 
lieutenants (interview with Rolando Davis, 2011). The conditions for peace were negotiated with Tomás Borge himself, and by November 1989, Palacios's group - the last of the Mayangna rebels - had demobilised (interview with Serapio Palacios, 2011).

\section{Autonomy and Identity}

By recognising that the Revolution's survival now depended on guaranteeing the peoples of the Coast cultural and political autonomy, the Sandinista government paved the way for peace on the Atlantic Coast. However, the autonomous political system established as a result of Sandinista negotiations with Miskitu, Mayangna and Creole communities, which split the region into two autonomous zones covering nearly half Nicaragua's national territory, fell far short of Mayangna expectations. Even with the bulk of the Mayangna population contained within a single autonomous zone - the RAAN - they were still vastly outnumbered there by the Miskitu, whose leaders - including a rehabilitated Steadman Fagoth - quickly came to dominate the regional autonomous political system.

This has led the Mayangna to repeat their old accusations that the Miskitu leaders claim to represent of all the 'Indians' of the RAAN, but ignore Mayangna problems (El Nuevo Diario, 02/07/2008). Most pressing of these is the invasion of Mayangna communal territories by Spanish-speakers from the west of Nicaragua, who illegally burn large swathes of forest to clear land for their crops, and later sell on the quickly-exhausted land to local mestizo cattle barons. This directly threatens the livelihoods of the Mayangna, who depend on the Coastal jungles for their food, medicine and building materials, and has resulted in violent confrontations between 
the Mayangna and the 'colonists' (Howard, 1998; see also La Prensa, 14/02/2011 and 28/03/2011).

The Mayangna response has been to declare themselves a separately constituted 'Nación Indígena' (El Nuevo Diario, 22/04/2009), spurring the creation of a new Mayangna nationalism and associated racial discourse - with its roots in the anti-'Spaniard' rhetoric of MISURASATA - that seeks to unpick the structures that allow for continued Miskitu domination. The Mayangna increasingly use the fact of Miskitu miscegenation with Europeans and Afro-descendents to undermine Miskitu attempts to portray themselves as the natural leaders of all the 'Indians' of the Coast, by denying that these leaders, or even the Miskitu people as a whole, are Indians in the first place. By dismissing the Miskitu as non-indigenous imposters - the offspring of 'blacks and gringos' (interview with Juan Frank, 2011) - and at the same time stressing their own position as 'the last pure indigenous people left in Nicaragua' (interview with Rolando Davis, 2011), the Mayangna try to increase their own status by claiming authenticity and purity, as proven by their 'Asian' - rather than 'black' physical characteristics (interview with Econayo Taylor, 2011; see also Frank and Erants, 2000) One problem with the emergence of this new, racialised discourse, however, is that the 'Twahka' Mayangna from around Wasakín, who have mixed more with outsiders and present a more heterogeneous appearance than the Panamahka from around Musawás, now risk being marginalised by their 'purer' cousins (Juan McKenzie, 2011; Carlos Sander, 2011).

Another consequence of what many Mayangna see as continued Miskitu domination has been the realignment of the Mayangna with Daniel Ortega's Sandinistas, who many Miskitu continue to regard with suspicion. Successive Liberal governments had neglected and obstructed the process of demarcating Mayangna 
lands (Howard, 1998). However, weeks before the 2006 elections in which Ortega finally regained power, he signed an agreement with the leaders of most of the sixtytwo Mayangna communities, pledging to 'promote the fight against racism and discrimination from the Executive', and 'advance the transparent execution... of the demarcation and titling of the indigenous territories of the Mayangna Nation' in exchange for their support (El Nuevo Diario, 30/10/2006).

While progress has been slow, Ortega's new administration has supported the formation of Mayangna territorial blocs that govern themselves independently of the RAAN's Miskitu-dominated autonomous political system. The Mayangna hope this will free them from Miskitu domination and the threat of further land invasions (interviews with Econayo Taylor, 2011; Rolando Davis, 2011; Murphy Almendárez, 2011). Thus the Mayangna now regard the Sandinistas as their only allies, and even Ampinio Palacios, the most determined of the Mayangna anti-Sandinista fighters during the 1980s and a consejo regional for the Constitutional Liberal Party after the war, has switched his support to Ortega. Emphasising the importance of Sandinista promises regarding territorial demarcation, he justifies the shift in his political allegiances by claiming that 'Our land is our only political party!' (Ampinio Palacios, 2011).

\section{Conclusions}

Miskitu influence over the Mayangna, dating back to the colonial era, increased during the first years of the Revolution through Miskitu control of the local Moravian Church hierarchy; through Sandinista promotion of the 'universal', Miskitudominated MISURASATA; and through the self-interest and political naivety of Mayangna leaders. The brutality of the civil war made Miskitu domination all the 
more overwhelming, as Sandinista violence drove thousands of poor and ill-educated Mayangna Indians - who had initially been receptive to the promises of the Revolution - to flee the country, straight into the arms of MISURA.

The legitimacy of Miskitu domination crumbled as violence on the Coast escalated, but the return of the Mayangna to Nicaragua only became possible after a genuine shift in the Sandinistas' own nationalist ideology. With an acknowledgement that real, important differences existed not only between mestizos and a unified 'Indian' other, but also between distinct groups of Indians, the Sandinistas demonstrated their growing understanding of the history and culture of the Coast. This enabled the Mayangna to rebuild their relationship with the Revolution, as equal partners rather than voices lost in the crowd.

Abuses suffered at the hands of Miskitu fighters define Mayangna wartime memories. Compounded by the fact that the Sandinistas were the first to reach out for an end to the disastrous conflict - with offers of an autonomy the Mayangna feel that Miskitu leaders have hijacked - many Mayangna now also see the outbreak of war in these terms. They blame their participation entirely on Miskitu 'trickery', while denying the role of either the Sandinistas or their own leadership in fomenting conflict on the Coast.

This troubled relationship with the Miskitu has influenced current Mayangna perceptions of their own ethnic identity, as they increasingly define themselves as 'the last real Indians in Nicaragua' in opposition to their supposedly 'mixed-blood' rivals. While this has helped to bolster Mayangna pride in their own culture and language, the new emphasis on physical characteristics as key to Mayangna identity is also problematic, creating discord between different Mayangna groups, not all of whom fit comfortably within the racially defined schemata that Mayangna leaders seek to 
construct in order to lay claim to regional prestige and influence. This has already resulted in the appearance of new divisions within a people for whom division has always proved disastrous.

The emphasis on Miskitu 'treachery' also risks blinding the Mayangna to the problems caused in both the past and present by their own leadership. Self-interest, corruption and a propensity toward caciquismo on the part of several key Mayangna leaders dragged entire communities - Musawás in particular - into the Civil War. Even more importantly, it obscures Mayangna recognition of the problems caused them by the Nicaraguan state. Despite Sandinista promises and Mayangna hopes, the central government remains reluctant to deal effectively with issue of peasant landinvasions, and with the alliance of big landowners, local capitalists, and crooked lawyers and politicians that makes the appropriation and theft of Mayangna lands possible. This only confirms that, as any dispassionate reading of Mayangna history will show, it is the Nicaraguan state, rather than any one people or political party, that has posed the greatest threat to the Mayangna since the annexation of their territories to Nicaragua in 1860.

\section{References}

Americas Watch Committee (1987) The Sumus in Nicaragua and Honduras: An Endangered People. Americas Watch: New York and Washington, D.C. 
Barricada - CIDCA-IHNCA (Archivos del centro de investigación y documentacion de la Costa Atlántica, in El Instituto de Historia de Nicaragua y Centroamérica, Universidad Centroamericana, Managua)

Borge, T. (Oct., 1985) Intervencion del commandante Tomás Borge en Puerto Cabezas - CIDCA-BICU (Archivos del centro de investigación y documentacion de la Costa Atlántica, in Bluefields Indian and Caribbean University, Bilwi/Puerto Cabezas)

Brooks, D. (1989) 'US Marines, Miskitos and the Hunt for Sandino: The Rio Coco Patrol in 1928,' in Journal of Latin American Studies, Vol. 21, No. 2

Carey, M. (2002) 'La influencia Mayangna (Sumu) en la historia de la Costa Atlántica Nicaragüense,' in Revista de Historia, No. 14

CIDCA (1984) Trabil Nani. Occasional Paper of the Riverside Church Disarmament Program: New York

CIDCA (1985) Situcación de los desplazados de guerra - Mina Rosita - CIDCABICU

Conzemius, E. (1929) 'Notes on the Miskito and Sumu Languages of Eastern Nicaragua and Honduras,' in International Journal of American Linguistics, Vol. 5, No. 1 
Conzemius, E. (1932) 'Ethnographical Survey of the Miskito and Sumu Indians of Honduras and Nicaragua,' in Bureau of American Ethnology, Bulletin 106

Dennis, P. (1981) 'The Costenos and the Revolution in Nicaragua', in Journal of Interamerican Studies and World Affairs, Vol. 23, No. 3

Dennis, P. (1993) 'The Miskito-Sandinista Conflict in Nicaragua in the 1980s', in Latin American Research Review, Vol. 28, No. 3

Dennis, P., and Olien, M. (1984) 'Kingship among the Miskito,'American Ethnologist, Vol. 11, No. 4, Social Structure and Social Relations

Dolores Green, R. (n.d.) Las viejas historias de los sumus, CIDCA - CIDCA-BICU

Dunbar Ortiz, R. (1986) La cuestión miskita en la revolución nicaragüense. Editorial Línea: Mexico City

Erants, M., and Frank, E. (2000) Historia oral del pueblo mayangna. URACCAN: Puerto Cabezas

Freedland, J. (1989) 'National Revolution and Ethnic Rights: the Miskitu Indians of Nicaragua's Atlantic Coast,' in Third World Quarterly, Vol. 11, No. 4

Gould, J. (1998) To Die In This Way: Nicaraguan Indians and the Myth of Mestizaje, 1880-1965. Duke University Press: Durham, NC 
Green, T. (1989) A Lexicographic Study of Ulwa. Unpublished doctoral dissertation, MIT, Cambridge, MT

Hale, C.R. (1994) Resistance and Contradiction: Miskitu Indians and the Nicaraguan State, 1894-1987. Stanford University Press: Palo Alto, CA

Hawley, S. (1997) 'Protestantism and Indigenous Mobilisation: The Moravian Church among the Miskitu Indians of Nicaragua,' in Journal of Latin American Studies, Vol. 29, No.1

Helms, M. W. (1969) 'The Cultural Ecology of a Colonial Tribe,' in Ethnology, Vol. 8, No. 1

Hooker, J. (2005) 'Beloved Enemies: Race and Official Mestizo Nationalism in Nicaragua,' in Latin American Research Review, Vol. 40, No. 3

von Houwald, G. (2006) Mayangna. Colección Cultural de Centro América: Managua

von Houwald, G., and Jenkins Molieri, J. (1975) 'Distribución y vivienda sumu en Nicaragua,' in Encuentro, Revista de la Universidad Centroamericana

Howard, S. (1998) 'Land Conflict and Mayangna Territorial Rights in Nicaragua's Bosawás Reserve,' in Bulletin of Latin American Research, Vol. 17, No. 1 
Hurtado de Mendoza, L. (2000) Identidad cultural mayangna en Nicaragua. Sociedad y Ambiente: Managua

ICI (1989), Misquitos y sumus refugiados Nicaragüenses en Honduras: Aportaciones para su repatriacion. ICI: Managua - CIDCA-IHNCA

INNICA (1981), Logros y problemas del gobierno revolucionario en la Costa Atlántica - CIDCA-IHNCA

Jenkins Molieri, J. (1986) El desafio indígena en Nicaragua: El caso de los miskitos. Editorial Vanguardia: Managua

La Prensa - CIDCA-INHCA

MISURASATA (1979), Lineamientos Generales - CIDCA-BICU

Nietschmann, B. (1989) The Unknown War: The Miskito Nation, Nicaragua, and the United States. Freedom House: New York

Norwood, S. (1987) 'El Sumu,' in Wani, No.6

El Nuevo Diario - CIDCA-INHCA 
Ohland, K., and Schneider, R. (1983) National Revolution and Indigenous Identity: the Conflict Between Sandinists and Miskito Indians on Nicaragua's Atlantic Coast. IWGIA: Copenhagen

Olien, M. (1988) 'After the Indian Slave Trade: Cross-Cultural Trade in the Western Caribbean Rimland, 1816-1820,' in Journal of Anthropological Research, Vol. 44, No. 1

SUKAWALA (1982), Plan rescate de ANCS - CIDCA-BICU

SUKAWALA (1985), Documento de guía para asemblea sumu, - CIDCA-BICU

Vilas, C. M., (trans. Susan Norwood), (1989) State, Class, and Ethnicity in Nicaragua: Capitalist Modernization and Revolutionary Change on the Atlantic Coast. L. Rienner Publishers: Boulder, Colorado

Wheelock, J. (1980) Raíces indígenas de la lucha anticolonialista en Nicaragua. Editorial Nueva Nicaragua: Managua

\section{Interviews}

Almendárez, Murphy (Managua, 1/4/ 2011)

Anonymous (Musawás, 26/4/2011) 
Blandón, Joaquín, (Musawás, 29/04/11)

Davis, Rolando ‘Chaolín’ (Bonanza, 22 /04/11)

Edwin Juwith, Armando (Españolina, 21/04/11)

Erants, Dionisio (Sakalwas, 25/04/11)

Fenley Pins, Cornelio (Wasakín, 18 /04/11)

Fernandez Taylor, Pichardo (Musawás, 29/04/11)

Frank, Eloy (Rosita, 17/04/11)

Frank, Juan (Rosita, 18/04/11)

Huete, Salvador (Musawás, 29/04/11)

Lau, Hazel (Puerto Cabezas, 11/04/11)

López, Enrique (Bonanza, 23/04/11)

McKenzie, Juan (Fruta de Pan, 17/04/11) 
Palacios, Ampinio (Bonanza, 26/04/11)

Palacios, Serapio (Musawás, 29/04/11)

Peralta Bans, Dalicio (Españolina, 21/04/11)

Patterson, Aurelia (Rosita, 20/04/11)

Sander, Carlos (Rosita, 20/04/11)

Simeón Palacios, Seperaida (Musawás, 29/04/11)

Taylor, Econayo (Bonanza, 23/04/11)

Zeledón, Erancio (Musawás, 29/04/11) 